\title{
Spectroscopic Investigation of Species Arising from CO Chemisorption on Titania-Supported Manganese
}

\author{
M argarita K antcheva, ${ }^{1}$ M ustafa U. Kucukkal, and Sefik Suzer \\ D epartment of Chemistry, B ilkent U niversity, 06533 B ilkent, A nkara, Turkey
}

R eceived J uly 27, 1999; revised N ovember 1, 1999; accepted N ovember 4, 1999

\begin{abstract}
The nature of manganese species on the surface of $\mathrm{TiO}_{2}$ (anatase) has been investigated by means of XPS, visible absorption spectroscopy, and FTIR spectroscopy of adsorbed C 0 . The catalysts were prepared by ion-exchange from aqueous manganese(II) chloride solution and impregnation. The application of ion-exchange results in a loading of manganese oxide phase corresponding to a monolayer coverage. On the surface of the ion-exchanged sample two kinds of $\mathrm{Mn}^{3+}$ ions are stabilized, differing in their coordinative saturation and localization. $\mathrm{The}^{\mathrm{Mn}^{3+}}$ ions form two kinds of linear carbonyls characterized by absorption at 2194 and $2187 \mathrm{~cm}^{-1}$, respectively. The impregnated catalyst contains a mixture of $\mathrm{Mn}^{3+}$ and $\mathrm{Mn}^{2+}$ species. The latter ions produce a carbonyl band at $2114 \mathrm{~cm}^{-1}$. The adsorption of $\mathrm{CO}$ at room temperature on the catalysts studied results in formation of formate, carbonate, and hydrogen carbonatestructures as well. It is found that theformation of formate species is associated with the $\mathrm{Mn}^{3+}$ ions and the possible mechanism is discussed. The stabilization of the hydrogen carbonates is favored by $\mathrm{Mn}^{2+}$ ions. The reduction of the catalyst studied with hydrogen strongly suppresses the adsorption of $\mathrm{CO}$ and is indicative of the occurrence of a strong metal-support interaction. (c) 2000 A cademic Press
\end{abstract}

Key Words: titania-supported manganese; XPS, visible absorption spectroscopy; FTIR of adsorbed CO.

\section{INTRODUCTION}

M anganese-containing oxide catalysts have wide application and potential use in a variety of catalytic processes of industrial importance. The nature of the manganese species in the catalysts is strongly influenced by the preparation conditions, such as the metal precursor, support used, loading, and calcination temperature (1-4), and several oxidation states may coexist.

The extensive surface studies previously reported concern mostly manganese oxides supported on alumina and different spectroscopic methods, such as XRD, XPS, ISS, $R$ aman and IR, TPD, and TPR, have been used (1-14) for their structural elucidation.

\footnotetext{
${ }^{1}$ To whom correspondence should be addressed. E-mail: margi@ fen.bilkent.edu.tr.
}

The IR spectroscopy of adsorbed $\mathrm{CO}$ is a useful technique applied for investigation of the surfaces of bulk and supported metal oxides (15). However, only a few studies (10, 13-20) (compared, for example, to those devoted to the catalytic performance) have appeared on the characterization of manganese oxide catalysts by this method. The reason for this could be the fact that manganese forms very complex species with oxygen, making characterization of manganese catalysts very difficult. For example, on the surface of $\mathrm{M} \mathrm{nO}_{2}$ no carbonyls have been detected because of oxidation of $\mathrm{CO}$ to carbonates (16). For this reason, in some experiments low-temperature adsorption of $\mathrm{CO}$ has been applied $(14,17)$. D ifficulties might arise from determination of the oxidation state of manganse by X PS due to the fact that it cannot be elucidated from the binding energy of either of the manganese main peaks ( $2 p$ or $3 p$ ) (21). In order to determine the oxidation state of manganese by this technique, the best approach (22) is to use the magnitude of $\mathrm{Mn}$ 3s splitting due to the coupling of the unpaired valence electrons with the core hole. Foord et al. (23) measured and tabulated the $M n 2 p_{3 / 2}$ binding energies and the $01 s: M n$ $2 p_{3 / 2}$ intensity ratios as well as $3 s$ multiplet splittings for stable $\mathrm{MnO}$ species. D etailed values of binding energies and the splitting of $\mathrm{Mn}$ 3s for different manganese oxides were summarized by $\mathrm{G}$ rzybek et al. (1) as well.

In this paper FTIR results on the interaction of $\mathrm{CO}$ at room temperature with the surface of manganese-titania catalysts containing $\mathrm{M} \mathrm{n}^{3+}$ and $\mathrm{M} \mathrm{n}^{2+}$ ions are presented. The oxidation state of the deposited manganese ions was determined by X PS taking into account the above considerations. The catalysts were characterized by visible absorption spectroscopy as well.

\section{EXPE RIME NTAL}

The support $\mathrm{TiO}_{2}$ (anatase) used is a commercial product (D egussa $P$ 25, surface area $52 \mathrm{~m}^{2} / \mathrm{g}$ ) containing $90 \%$ anatase and $10 \%$ rutile.

The ion-exchanged sample was prepared by suspending the support powder in a $0.2 \mathrm{M}$ aqueous solution of $\mathrm{M} \mathrm{nCl}_{2}$ for $2 \mathrm{~h}$ followed by alkalization $(\mathrm{pH} 13)$ of the mixture with 


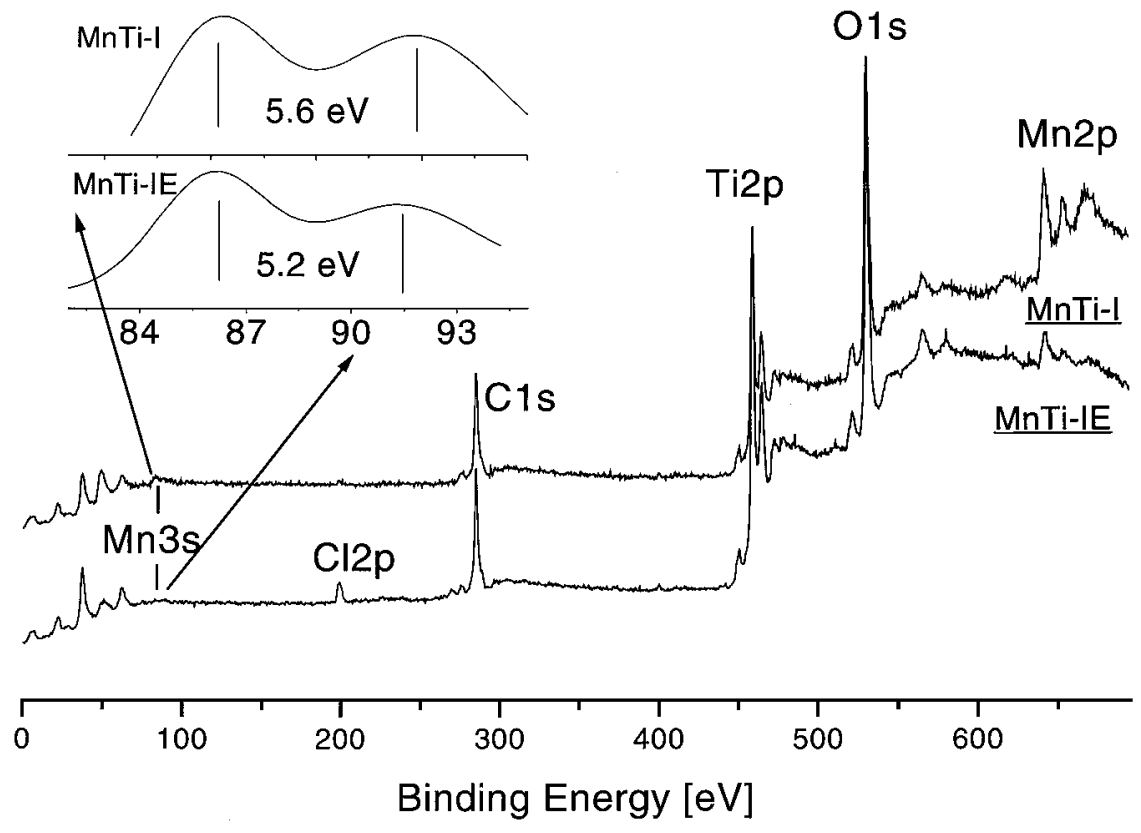

FIG. 1. X-ray photoelectron spectra of the catalysts studied.

aqueous ammonia ( $1: 1)$ and immediate filtration. Then the product was washed with deionized water, dried in air at $383 \mathrm{~K}$, and calcined for $1 \mathrm{~h}$ at $623 \mathrm{~K}$ and then for $1 \mathrm{~h}$ at $723 \mathrm{~K}$. This sample is denoted by $\mathrm{M} \mathrm{nTi}-\mathrm{IE}$.

The impregnated sample was obtained by the incipient wetness technique ( 4 wt $\%$ of nominal manganese content) using $\mathrm{M} \mathrm{nCl}_{2}$ solution which was alkalized with ammonia to $\mathrm{pH} 13$ in the last stage of the preparation procedure. The calcination procedure was the same as that used for the ionexchanged catalyst. For this sample the notation M nTi-I is used. The chemical analysis of manganese was performed by flame atomic absorption spectrometry at the respective resonance wavelength. The manganese content in the ionexchanged catalyst is $1.9 \mathrm{wt} \%$.

The XPS spectra were taken with a KRATOS ES300 spectrometer equipped with a $\mathrm{MgK} \alpha$ radiation source. The visible absorption spectra were recorded with a Cary $5 \mathrm{E} U \mathrm{~V}$-vis-NIR spectrometer. The reference substance was the catalyst support, titania. The FTIR spectra were recorded with a Bomem-MB102 (Hartmann \& Braun) FTIR spectrometer at a spectral resolution of $4 \mathrm{~cm}^{-1}$ (256 scans). A specially designed IR cell allowed recording of the spectra at ambient temperature and catalyst activation at higher temperatures. The cell was connected to a vacuum/adsorption apparatus. Self-supporting discs were used for the FTIR studies.

The samples were activated in the IR cell by evacuation at $673 \mathrm{~K}$ for $1 \mathrm{~h}$, heating at 100 Torr $^{2}$ of oxygen for $1 \mathrm{~h}$ at $673 \mathrm{~K}$, and evacuation for $1 \mathrm{~h}$ at the same temperature.

\footnotetext{
${ }^{2} 1$ Torr $=133.3 \mathrm{~N} \mathrm{~m}^{-2}$.
}

Partial deuteroxylation of the manganese-containing samples was achieved by introduction to the evacuated IR cell of $\mathrm{D}_{2} \mathrm{O}(99.9 \%)$ vapor at 3 Torr for $15 \mathrm{~min}$ at $673 \mathrm{~K}$ and evacuation for $30 \mathrm{~min}$ at the same temperature. This procedure was repeated two times. Then the activation procedure described above was employed. The reduction of the catalysts was performed with hydrogen (200 Torr, $673 \mathrm{~K}$, for $30 \mathrm{~min}$ ) and after that the samples were evacuated at the same temperature for $30 \mathrm{~min}$. This procedure was repeated two times. A fter the final reduction, the samples were evacuated at $673 \mathrm{~K}$ for $1 \mathrm{~h}$. The spectra of the catalysts thus activated were taken at ambient temperature and used as a background reference.

The carbon monoxide (99.95\% ) used was passed through a trap cooled by liquid nitrogen before admission to the IR cell.

\section{RESULTS}

\section{XPS}

The XPS spectra of the MnTi-I and MnTi-IE samples are shown in Fig. 1. In order to differentiate between the different oxidation states of manganese, the magnitude of $3 \mathrm{~s}$ multiplet splitting is used as al ready mentioned. The values are 5.6 and $5.2 \mathrm{eV}$ for the impregnated and ion-exchanged samples, respectively. B ased on this, we can determine (1, $22,23)$ that a mixture of $\mathrm{Mn}^{2+}$ and $\mathrm{Mn}^{3+}$ ions is present on the surface of the $\mathrm{MnTi}-\mathrm{I}$ sample and only $\mathrm{Mn}^{3+}$ ions are present on the $\mathrm{MnTi}$-IE catalyst. The $\mathrm{Mn} 2 \mathrm{p}_{3 / 2}$ binding energy has a value of $642 \mathrm{eV}$ for both catalysts which is similar to those of bulk manganese oxides (640.5-643 eV ) 


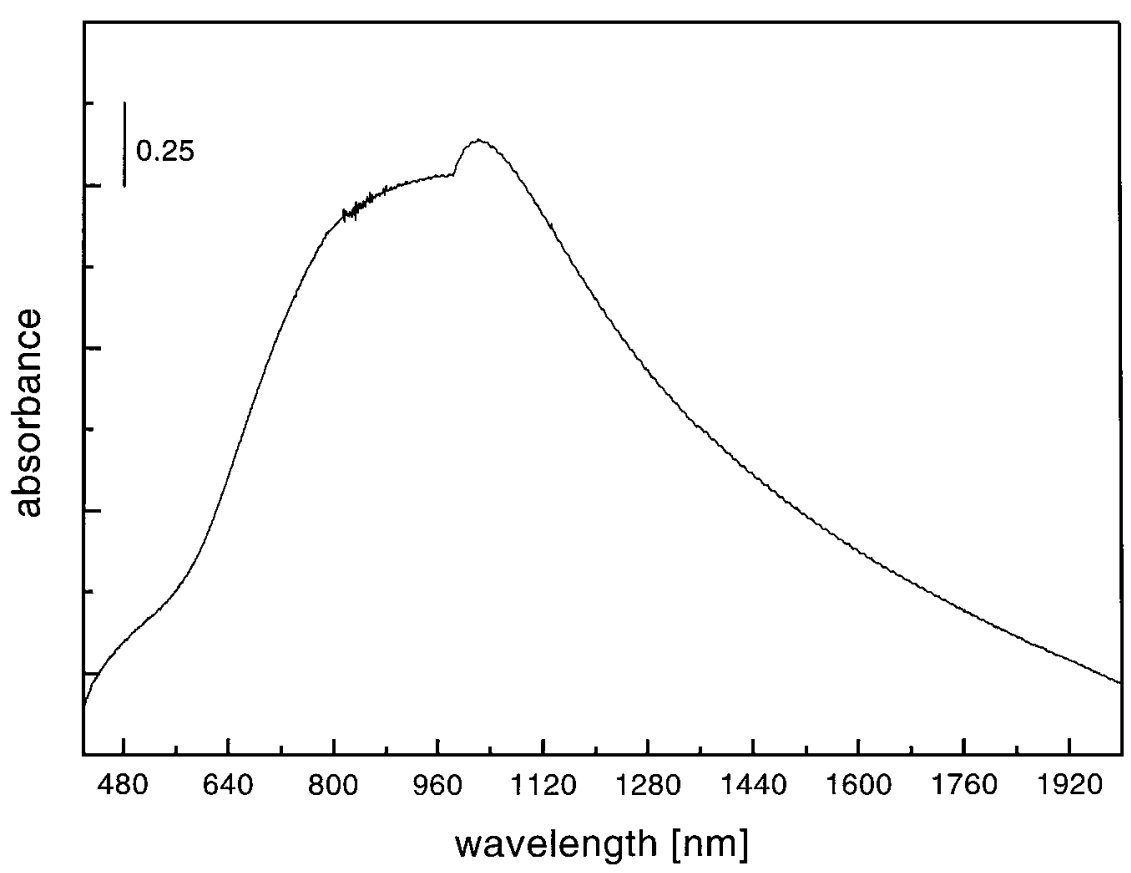

FIG. 2. A bsorption spectrum in the visible range of catalyst $\mathrm{M} \mathrm{nTi-IE}$ taken under ambient conditions.

$(1,23)$. From this value it is difficult to estimate the degree of interaction of the deposited manganese ions with the surface of the support.

\section{Visible A bsorption Spectroscopy}

The visible absorption spectrum of the catalyst $\mathrm{MnTi}$ IE taken in the 300-2000-nm region displays a broad step curve with a large overall absorption due to the dark color of the sample (Fig. 2). Two distinct maxima between 700900 and at about $1025 \mathrm{~nm}$ are observed which correspond to different $\mathrm{d}-\mathrm{d}$ transitions of $\mathrm{M} \mathrm{n}^{3+}$ ions (24).

It was not possible to obtain the visible absorption spectrum of the catalyst $\mathrm{M} \mathrm{nTi-I} \mathrm{by} \mathrm{application} \mathrm{of} \mathrm{the} \mathrm{same} \mathrm{tech-}$ nique because of the very strong absorption of this sample.

\section{FTIR Spectra of the A ctivated Samples}

Figure 3 shows the FTIR spectra in the $\mathrm{OH}$ stretching region of the activated catalysts and the support $\mathrm{TiO}_{2}$. In the same figure the spectrum of the catalyst M nTi-IE obtained after reduction with hydrogen at $673 \mathrm{~K}$ is also given. A series of bands between 3735 and $3640 \mathrm{~cm}^{-1}$ characteristic for anatase (25) are observed in the spectrum of the support. The band at $3745 \mathrm{~cm}^{-1}$, according to some authors $(26,27)$, is due to presence of silicon. The extent of the participation of the surface $\mathrm{OH}$ groups of the support in the process of manganese deposition depends on the method of preparation used. The low-frequency (i.e., the more acidic) $\mathrm{OH}$ groups of the support are involved to a larger extent in the impregnation process whereas the reverse is observed in the ion-exchange process. The $\mathrm{MnTi}$-I catalyst exhibits

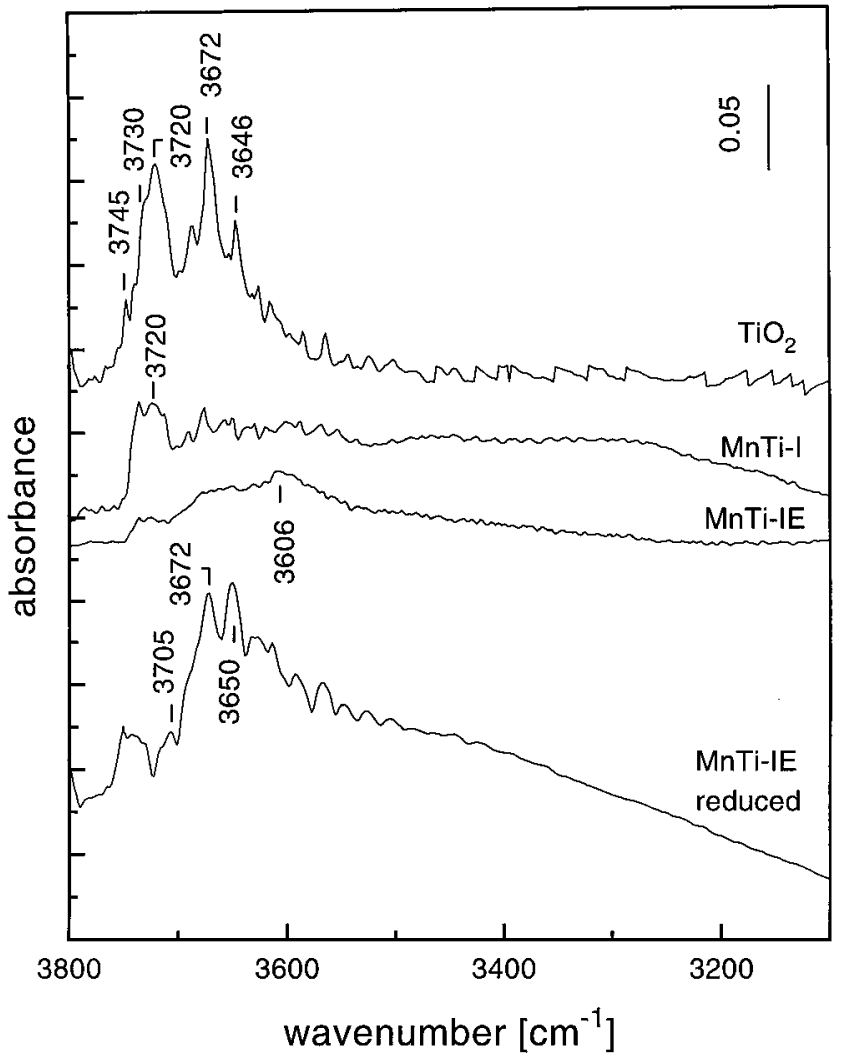

FIG. 3. FTIR spectra of the catalysts studied in the $\mathrm{OH}$ stretching region. 
a broad band between $3550-3200 \mathrm{~cm}^{-1}$ which indicates the presence of $\mathrm{H}$-bonded hydroxyl groups. A certain amount of hydrogen-bonded hydroxyls are observed also on the $\mathrm{M} \mathrm{nTi-IE} \mathrm{sample.} \mathrm{From} \mathrm{these} \mathrm{experimental} \mathrm{data} \mathrm{it} \mathrm{is} \mathrm{difficult}$ to determine if the residual $\mathrm{OH}$ groups of the manganesecontaining catalysts are of $\mathrm{Ti}^{4+}-\mathrm{OH}$ type or are coordinated to manganese ions. No other bands are detected at lower wavenumbers.

The reduction of $\mathrm{MnTi}-\mathrm{IE}$ catalyst causes significant changes in the spectrum in the $\mathrm{OH}$ stretching region. It seems that part of the original $\mathrm{OH}$ groups of the support are restored. In addition, there is a considerable amount of $\mathrm{H}$-bonded $\mathrm{OH}$ groups.

\section{FTIR Spectroscopy of A dsorbed CO}

4.1. The support $\mathrm{TiO}_{2}$. $\mathrm{CO}$ adsorption (30 Torr) at room temperature on the $\mathrm{TiO}_{2}$ sample leads to the appearance of two bands with maxima at 2206 and $2188 \mathrm{~cm}^{-1}$ (Fig. 4). They are characteristic of the $\mathrm{CO}$ stretching modes of two kinds of $\mathrm{Ti}^{4+}-\mathrm{CO}$ surface carbonyls, formed with the participation of the strong $(\alpha)$ and weak $\left(\beta^{\prime}\right)$ L ewis acid sites, respectively $(25,28-30)$. The intensities of these bands do not change with the time at constant $\mathrm{CO}$ pressure and the surface $\mathrm{Ti}^{4+}-\mathrm{OH}$ groups are not affected by the adsorbed

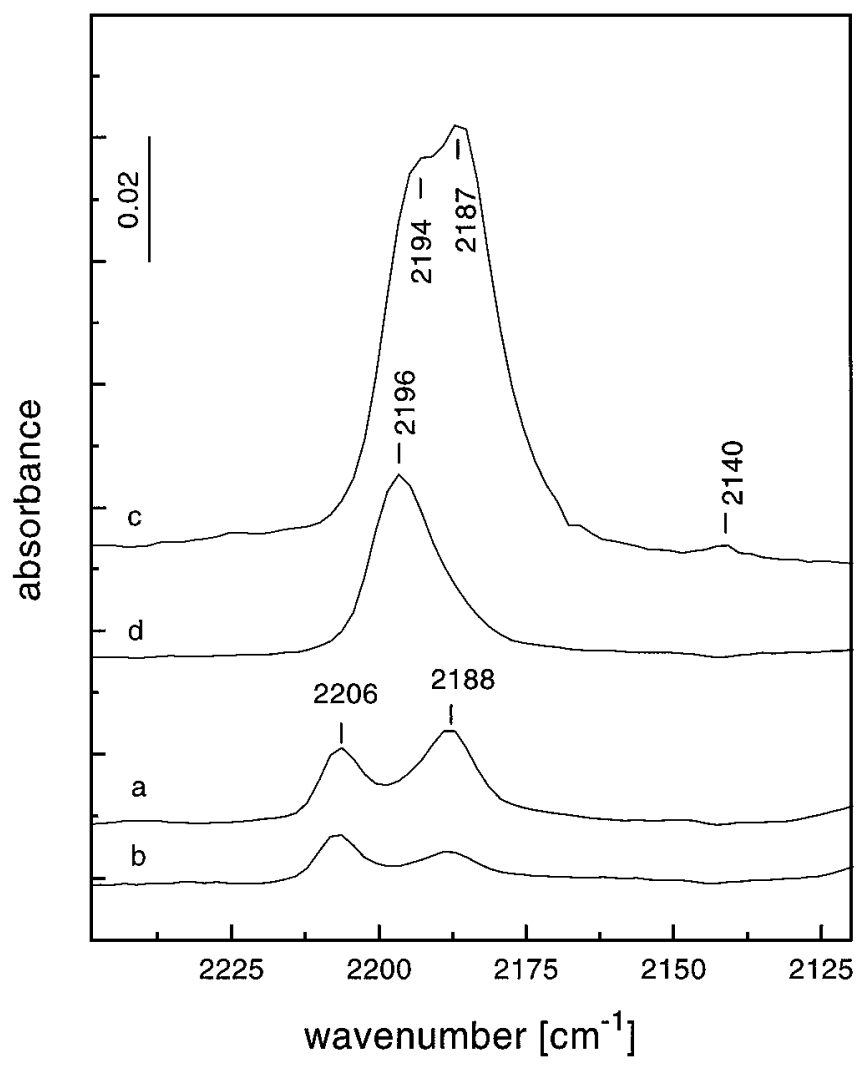

FIG. 4. FTIR spectra in the carbonyl region of adsorbed $\mathrm{CO}$ at room temperature on $\mathrm{TiO}_{2}$ (anatase) at 30 Torr (a) and 1 Torr (b), and on M nTiIE catalyst at 30 Torr (c) and 1 Torr (d).
CO. No other adsorbed species are observed under these conditions.

4.2. The MnTi-IE sample. The adsorption of $\mathrm{CO}$ at 30 Torr (room temperature) on the activated M nTi-IE catalyst (Fig. 4) leads to formation of two types of $\mathrm{M} \mathrm{n}^{3+}-\mathrm{CO}$ carbonyls (FTIR bands at 2194 and $2187 \mathrm{~cm}^{-1}$, respectively). The higher frequency and stability of the carbonyl manifesting band at $2194 \mathrm{~cm}^{-1}$ (which is present in the spectrum taken at 1 Torr of $\mathrm{CO}$ ) are indicative of the greater acidity of the respective adsorption sites. The $v(\mathrm{CO})$ stretching frequencies of the corresponding carbonyls are very close to those observed on the anatase surface. The arguments for assignment of the bands at 2194 and $2187 \mathrm{~cm}^{-1}$ to two different kinds of $\mathrm{M} \mathrm{n}^{3+}-\mathrm{CO}$ carbonyls are based on the XPS results, the behavior of these species in a $\mathrm{CO}$ atmosphere (see below), and the band intensities (about 5 times more intense than the $\mathrm{Ti}^{4+}-\mathrm{CO}$ carbonyl bands).

The spectrum of the M nTi-IE catalyst in the carbonyl region is characterized by another weak absorption at $2140 \mathrm{~cm}^{-1}$. This band can be associated with $\mathrm{M} \mathrm{n}^{2+}$ ions, whose amount is low and below the X PS detection limits. A nother possibility could be the formation of these species during $\mathrm{CO}$ adsorption. A II the carbonyls detected are unstable and disappear from the spectrum upon evacuation of $\mathrm{CO}$ at room temperature.

The adsorption of $\mathrm{CO}$ on the manganese-containing samples is a time-dependent process. In order to follow better the behavior of the surface hydroxyl groups after admission of $\mathrm{CO}$ into the IR cell, a partially deuteroxylated M nTi-IE sample was used. The development of the spectra with the time at constant $\mathrm{CO}$ pressure (30 Torr) is shown in Fig. 5. The increase in the time of $\mathrm{CO}$ adsorption causes a gradual increase of the bands in the carbonate-carboxylate region (2000-1040 $\mathrm{cm}^{-1}$ ). Simultaneously, the bands detected in the carbonyl region, at 2194 and $2187 \mathrm{~cm}^{-1}$, decrease in intensity. It should be pointed out that the carbonyl bands of the partially deuteroxylated sample have a different intensity ratio compared to that of the hydroxylated sample. $O$ bviously, the reason for this is the high-temperature treatment with $\mathrm{D}_{2} \mathrm{O}$ vapor which causes some structural changes. The decrease in the intensity of the carbonyl bands is accompanied by a strong enhancement of the adsorption in the $2400-2300-\mathrm{cm}^{-1}$ region. The band at $2347 \mathrm{~cm}^{-1}$ is due to adsorbed $\mathrm{CO}_{2}$ (31) and its growth with the time indicates that oxidation of $\mathrm{CO}$ to $\mathrm{CO}_{2}$ occurs. In the $\mathrm{OH} / \mathrm{OD}$ stretching region (3650-3000/2740-2500 $\mathrm{cm}^{-1}$ ), with the increase of the $\mathrm{CO}$ contact time, the absorption due to $\mathrm{H} / \mathrm{D}$-bonded OH/O D groups rises in intensity. A the same time the negative band at $3730 / 2750 \mathrm{~cm}^{-1}$ due to isolated $\mathrm{Ti}^{4+}-\mathrm{OH} / \mathrm{Ti}^{4+}-\mathrm{OD}$ groups gradually grows. The appearance of a positive absorption at 2668 and $3616 \mathrm{~cm}^{-1}$, respectively, which is enhanced with time, is clearly observed. A fter $67 \mathrm{~min}$ of $\mathrm{CO}$ adsorption, the completely hydroxylated sample (spectrum $\mathrm{f}$ in Fig. 5) displays the same bands 


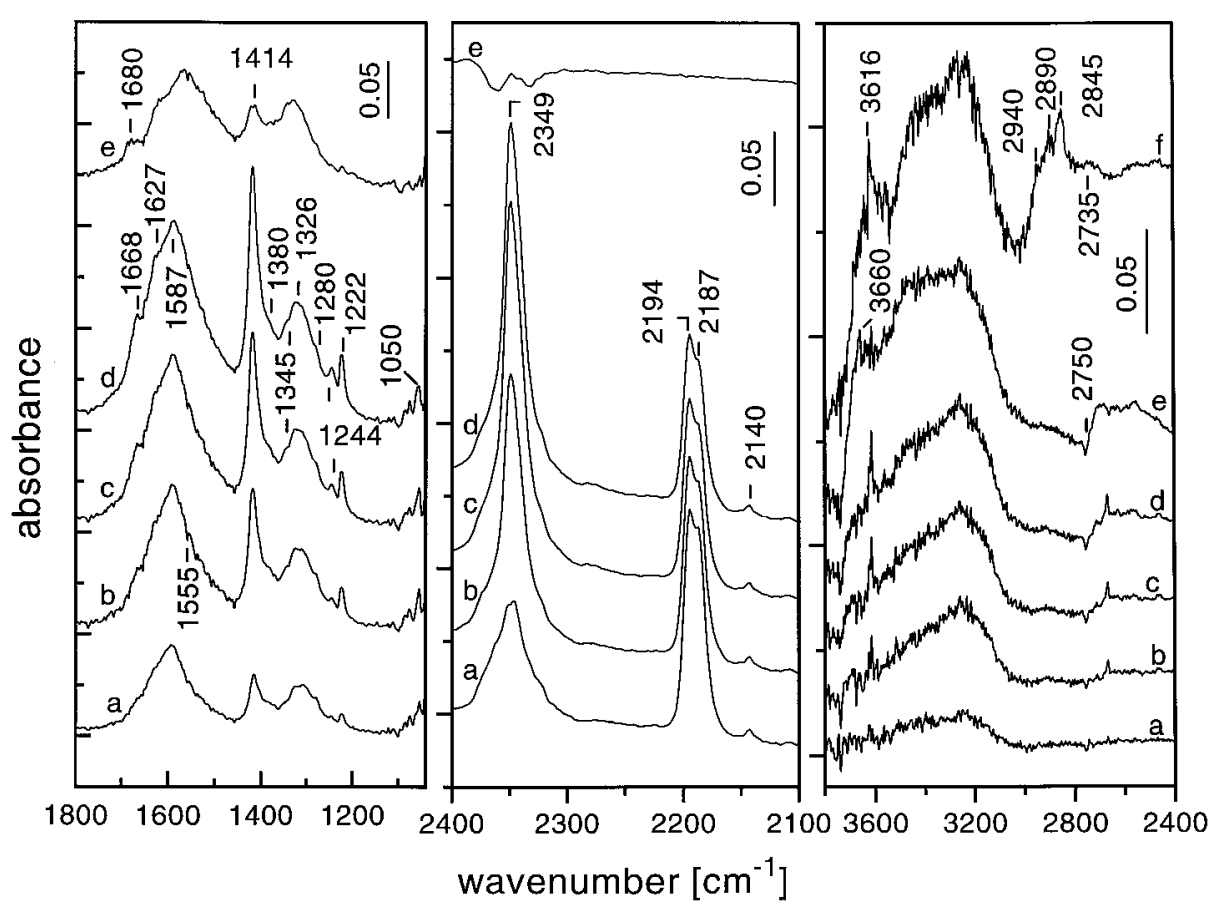

FIG. 5. FTIR spectra of adsorbed CO (30 Torr) at room temperature on partially deuteroxylated M nTi-IE catalyst for various times: immediately after admission of CO to the IR cell (a); after $10 \mathrm{~min}$ (b); after $42 \mathrm{~min} \mathrm{(c);} \mathrm{after} 67 \mathrm{~min}$ (d); and after evacuation at room temperature for $10 \mathrm{~min}$ (e). The spectrum of hydroxylated $\mathrm{M} \mathrm{nTi-IE} \mathrm{catalyst} \mathrm{in} \mathrm{the} \mathrm{OH}$ stretching region after $67 \mathrm{~min}$ in $\mathrm{CO}$ (30 Torr) is also shown (f).

detected in the partially deuteroxylated M nTi-IE catalyst in the $\mathrm{OH}$ portion of the spectrum. However, a group of bands at 2940, 2890, and $2845 \mathrm{~cm}^{-1}$ together with the broad and weak absorption at about $2735 \mathrm{~cm}^{-1}$ are detected in the $\mathrm{CH}$ stretching region. The corresponding $\mathrm{CD}$ stretching vibrations are not observed because they fall in the region of the strong carbonyl bands (2230-2160 $\left.\mathrm{cm}^{-1}\right)$.

A fter evacuation for $10 \mathrm{~min}$ at room temperature the carbonyl bands and the band due to adsorbed $\mathrm{CO}_{2}$ disappear from the spectrum. The bands in the $\mathrm{CH}$ stretching (not shown in the Fig. 5) and carbonate-carboxylate regions are observed with reduced intensities. U nder these conditions new bands at about 1680 and $3660 \mathrm{~cm}^{-1}$ emerge in the spectrum.

The species in the carboxylate-carbonate region obtained upon $\mathrm{CO}$ adsorption display low thermal stability: the intensities of the corresponding bands decrease strongly and almost simultaneously after evacuation for $5 \mathrm{~min}$ at $373 \mathrm{~K}$. The heating at $423 \mathrm{~K}$ leads to complete desorption.

Figure 6 compares the spectra of adsorbed CO (30 Torr) 67 min after its admission to the IR cell on the reduced and oxidized $\mathrm{MnTi-IE}$ samples. A fter reduction the spectrum in the carbonate-carboxylate region becomes simpler and the absorption in the carbonyl region is considerably weaker. It is difficult to determine if the carbonyl band at $2189 \mathrm{~cm}^{-1}$ is due only to unreduced $\mathrm{M} \mathrm{n}^{3+}$ ions or if there is a contribution from the exposed $\beta^{\prime}-\mathrm{Ti}^{4+}$ ions. The possibility of assigning this absorption only to exposed $\mathrm{Ti}^{4+}$ ions can be ruled out because of the appearance of carbonatecarboxylate structures-a situation similar to that already observed with the oxidized M nTi-IE sample. A s in the latter case, a weak absorption at about $2140 \mathrm{~cm}^{-1}$ is also detected. The simultaneous decrease of the bands at 1414 and $1222 \mathrm{~cm}^{-1}$ after reduction indicates that they belong to the same surface species. The complex and intense bands centered at about 1550 and $1340 \mathrm{~cm}^{-1}$ resemble part of the spectrum observed on the oxidized sample, but with lower band intensities. The absorption in the $\mathrm{OH}$ and $\mathrm{CH}$ stretching regions detected after $\mathrm{CO}$ admission is similar to that of the oxidized sample but less intense.

4.3. The M nT-I sample. The adsorption of $\mathrm{CO}$ was also performed over a partially deuteroxylated sample. In this case, however, the establishment of the equilibrium between the gas phase and the adsorbed species was slower. The complex band in the carbonyl region at $2186 \mathrm{~cm}^{-1}$ reached maximum intensity 10 min after admission of $\mathrm{CO}$ (30 Torr) into the IR cell.

U nder the conditions described, together with the band at $2186 \mathrm{~cm}^{-1}$ (which has a shoulder at about $2194 \mathrm{~cm}^{-1}$ ), two weak bands at 2144 and $2114 \mathrm{~cm}^{-1}$ are observed in the carbonyl region (Fig. 7). The absorption at $2144 \mathrm{~cm}^{-1}$ cannot be assigned to the $v(C D)$ stretching mode because it is detected also in the hydroxylated M nTi-IE and MnTi-I samples. Taking into account the X PS results on the $\mathrm{M} \mathrm{nTi-I}$ catalyst and the FTIR data on the M nTi-IE sample, the 


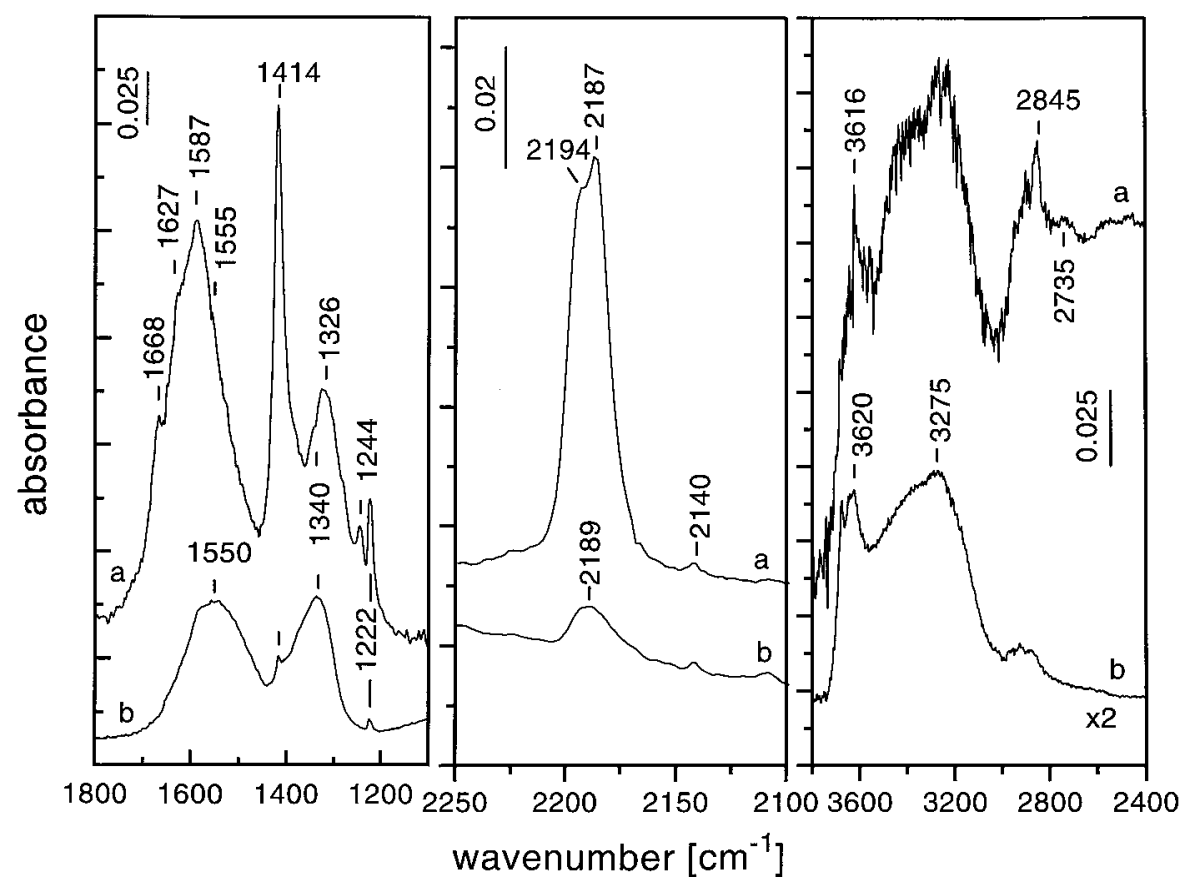

FIG. 6. FTIR spectra of adsorbed CO ( 30 Torr) at room temperature on M nTi-IE catalyst (a) and after reduction with hydrogen at $673 \mathrm{~K}$ (b).

complex adsorption with the maximum at $2186 \mathrm{~cm}^{-1}$ can be attributed to the two types of $\mathrm{Mn}^{3+}-\mathrm{CO}$ carbonyls, whereas the two weak bands are assigned to different kinds of $\mathrm{M} \mathrm{n}^{2+}-\mathrm{CO}$ species.
With an increase in contact time, the intensity of the unresolved band due to the $\mathrm{M} \mathrm{n}^{3+}-\mathrm{CO}$ carbonyls gradually decreases, whereas the population of the $\mathrm{Mn}^{2+}-\mathrm{CO}$ carbonyls showing absorption at $2114 \mathrm{~cm}^{-1}$ is enhanced

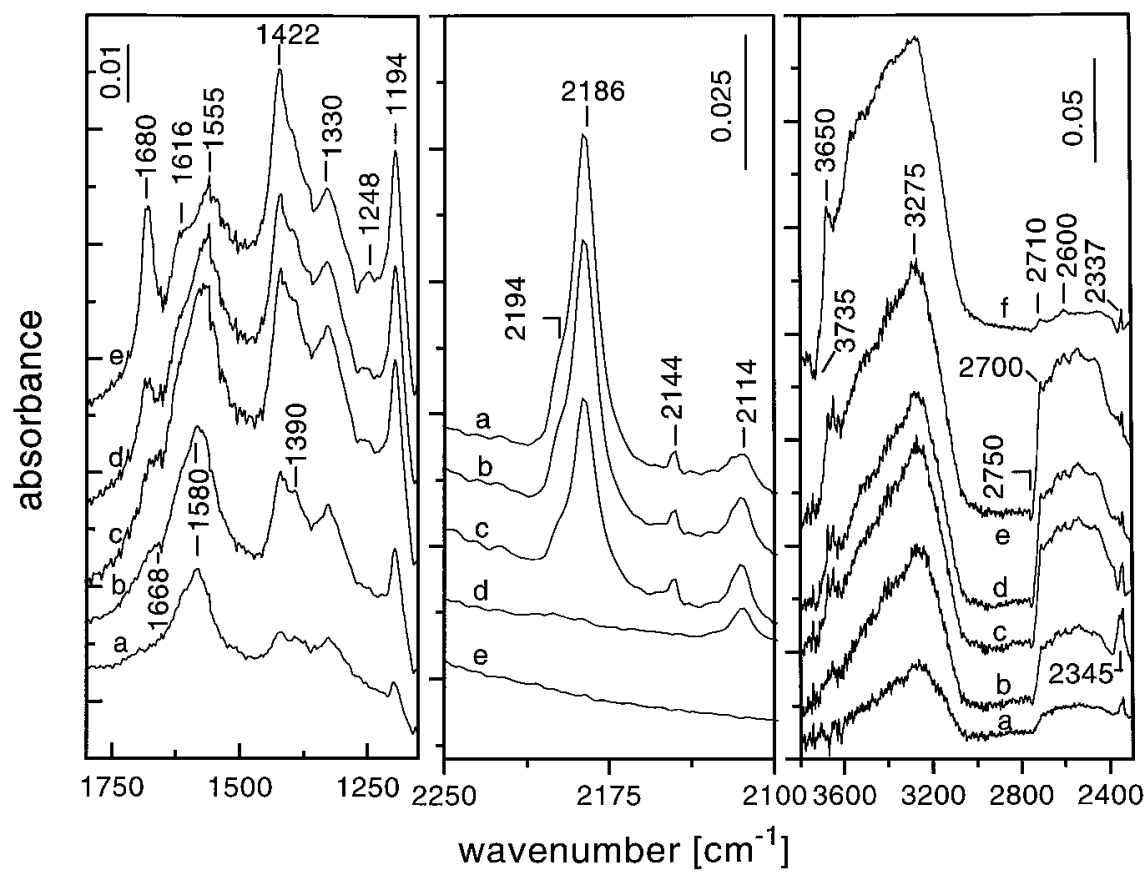

FIG. 7. FTIR spectra of adsorbed CO (30 Torr) at room temperature on partially deuteroxylated M nTi-I catalyst for various times: after 10 min (a); after $50 \mathrm{~min}(\mathrm{~b})$; after $100 \mathrm{~min}(\mathrm{c})$; and after evacuation at room temperature for 2 min (residual pressure, $p=3.5 \times 10^{-1}$ Torr) (d) and for $10 \mathrm{~min}$ $\left(p=3.3 \times 10^{-3}\right.$ Torr) (e). The spectrum of hydroxylated M nTi-l catalyst in the OH stretching region after $67 \mathrm{~min}$ in $\mathrm{CO}$ ( $30 \mathrm{Torr}$ ) is also shown ( $\mathrm{f}$ ). 
almost 2 times after $100 \mathrm{~min}$. The intensity of the band corresponding to $\mathrm{Mn}^{2+}-\mathrm{CO}$ carbonyls represented by the absorption at $2144 \mathrm{~cm}^{-1}$ seems not to be affected by time. In the carbonate-carboxylate region, with increase of exposure time numerous bands develop, which can be grouped as follows (see the arguments below): (i) the set of bands with maxima at 1650-1500 and 1400-1250 $\mathrm{cm}^{-1}$ and (ii) the bands at 1680, 1422, and $1194 \mathrm{~cm}^{-1}$.

A sin the case of the M nTi-IE catalyst the absorption due to $\mathrm{H} / \mathrm{D}$-bonded OH/O D groups ( $3800-2400 \mathrm{~cm}^{-1}$ ) grows in intensity with extent of contact time. Thisis accompanied by appearance of a negative $O D$ band at $2750 \mathrm{~cm}^{-1}$ indicating that consumption of isolated $\mathrm{Ti}^{4+}-\mathrm{OD}$ groups takes place. A sharp band at 2700 and $3650 \mathrm{~cm}^{-1}$, respectively, corresponding to formation of isolated $\mathrm{OD} / \mathrm{O} \mathrm{H}$ groups increases in intensity. $\mathrm{H}$ ere again, evolution of $\mathrm{CO}_{2}$ is observed, which is detected by the appearance of two bands between 2400 and $2300 \mathrm{~cm}^{-1}$ due to adsorbed $\mathrm{CO}_{2}$. These bands reached maximum intensity after $30 \mathrm{~min}$ of contact with $\mathrm{CO}$ (not shown in Fig. 7) and started to decay at more prolonged ( 50 min and above) adsorption times. This is an indication that transformation of the adsorbed $\mathrm{CO}_{2}$ into other surface forms occurs.

Figure 7 shows also the spectrum of hydroxylated $\mathrm{M} \mathrm{nTi-I}$ catalyst in the $\mathrm{OH}$ stretching region taken after $67 \mathrm{~min}$ of $\mathrm{CO}$ adsorption (spectrum $\mathrm{f}$ ). It is characterized by the same spectral featuresin the $\mathrm{OH}$ stretching region observed for the deuteroxylated sample. In addition, it contains two weak bands at 2710 and $2600 \mathrm{~cm}^{-1}$ which correspond to $v(\mathrm{CH})$ stretching modes.

The evacuation of the deuteroxylated sample at room temperature to different residual pressures (Fig. 7, spectra $\mathrm{d}$ and e) causes the following changes in the IR spectra:

(i) G radual increase is observed in the intensity of the $\mathrm{H} / \mathrm{D}$-bonded $\mathrm{OH} / \mathrm{OD}$ groups and that of isolated $\mathrm{OH} / \mathrm{OD}$ groups characterized by the absorption at $3650 / 2700 \mathrm{~cm}^{-1}$.

(ii) The absorption corresponding to $\mathrm{M} \mathrm{n}^{3+}-\mathrm{CO}$ species and the band at $2144 \mathrm{~cm}^{-1}$ disappear from the spectrum at a residual pressure of $3.5 \times 10^{-1}$ Torr. The carbonyl species characterized by the $v(\mathrm{CO})$ stretching frequency at $2114 \mathrm{~cm}^{-1}$ resist the short evacuation which is consistent with their assignment to $\mathrm{M} \mathrm{n}^{2+}-\mathrm{CO}$ carbonyls.

(iii) In the carbonate-carboxylate region the set of bands at 1680,1422 , and $1194 \mathrm{~cm}^{-1}$ increases in intensity. This increase is at the expense of the complex bands centered at 1580 and $1330 \mathrm{~cm}^{-1}$ and is more pronounced at a residual pressure of $3.3 \times 10^{-3}$ Torr. This is an indication that under these conditions transformation of some surface species into others takes place.

The changes described in the spectra are more clearly visible in the subtraction spectra (Fig. 8) obtained from the spectra recorded after $10 \min \left(p=3.3 \times 10^{-3}\right.$ Torr $)$ and $4 \mathrm{~min}$ of evacuation $\left(p=5.5 \times 10^{-3}\right.$ Torr $)$, respec-

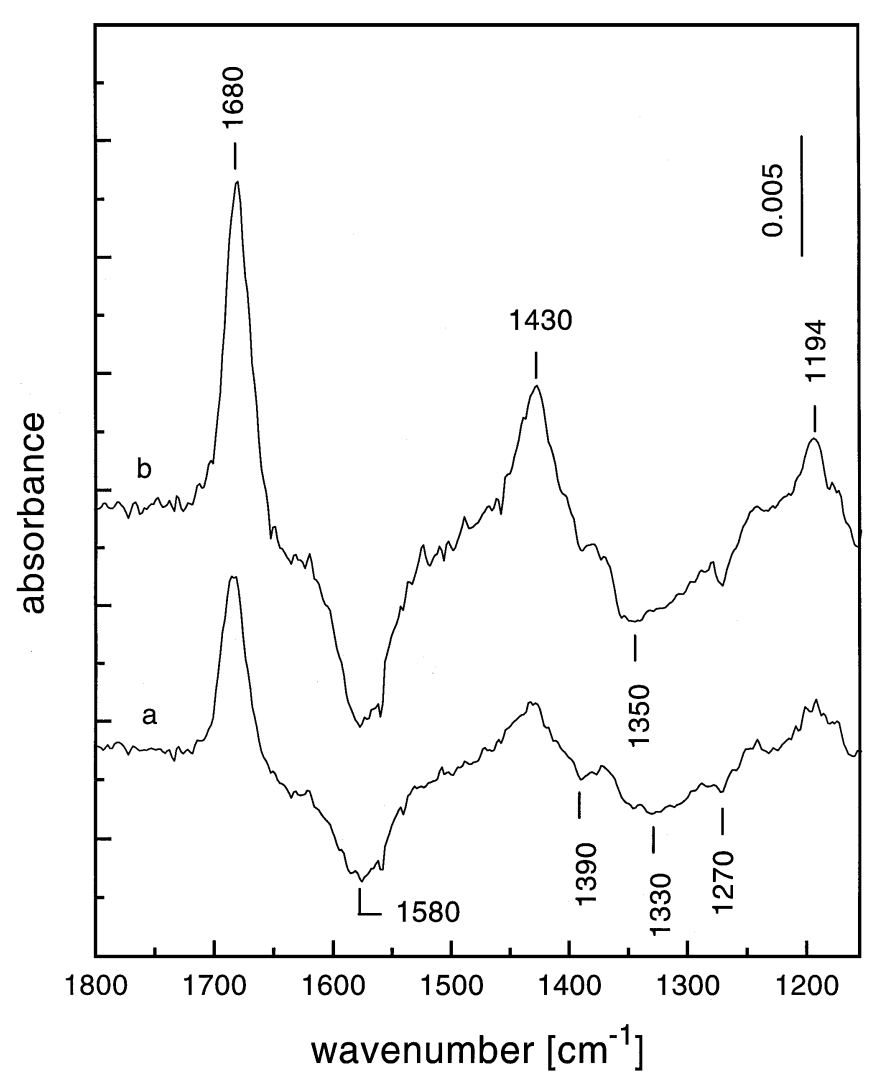

FIG. 8. FTIR spectra of partially deuteroxylated M nTi-I catalyst in the carbonate-carboxylate region obtained by subtraction of the spectrum of adsorbed $\mathrm{CO}$ (30 Torr) followed by evacuation for 2 min at room temperature ( $p=3.5 \times 10^{-1}$ Torr) from the spectrum after 4 min of evacuation ( $p=5.5 \times 10^{-3}$ Torr) (a) and from the spectrum after $10 \mathrm{~min}$ of evacuation ( $p=3.3 \times 10^{-3}$ Torr) (b).

tively, minus that taken after 2 min of evacuation $(p=$ $3.5 \times 10^{-1}$ Torr). The constant intensity ratio between the bands at 1680, 1430, and $1194 \mathrm{~cm}^{-1}$ which is observed at different evacuation times and different residual pressures in the IR cell, respectively, indicates that these bands belongs to the same surface species. Similarly, it is concluded that the absorption in the $1650-1500-\mathrm{cm}^{-1}$ region together with the complex band centered at $1330 \mathrm{~cm}^{-1}$ characterizes another surface species.

A fter reduction of the $\mathrm{MnTi-I}$ sample no bands in the carbonyl and carbonate-carboxylate region are detected upon $\mathrm{CO}$ adsorption.

\section{R oom-Temperature A dsorption of Formic A cid on the M nTi-IE Sample}

The FTIR spectrum of the formic acid used in the adsorption experiments is characterized by the following bands: a broad and intense absorption with a maximum at $3430 \mathrm{~cm}^{-1}$ due to $v(\mathrm{OH})$ of $\mathrm{H}$-bonded $\mathrm{OH}$ groups, bands with maxima at $2947(v(\mathrm{CH}))$ and $1718 \mathrm{~cm}^{-1}(v(\mathrm{C}=0))$, a group of bands at 1396 and $1380-1320 \mathrm{~cm}^{-1}$ both due to coupling 


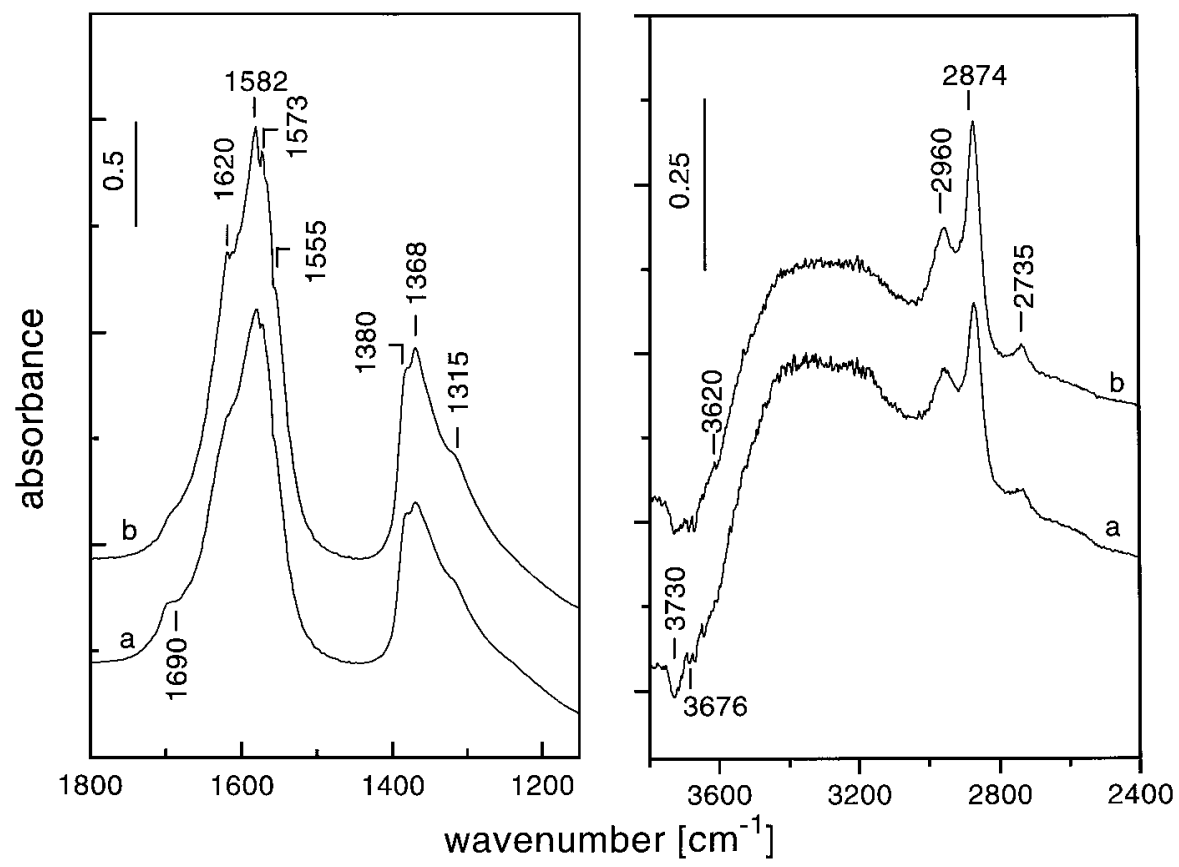

FIG. 9. FTIR spectra of adsorbed formic acid ( 0.5 Torr) on M nTi-IE catalyst (a) and after 10 min of evacuation at room temperature (b).

between in-plane $\mathrm{O}-\mathrm{H}$ bending and $\mathrm{C}-\mathrm{O}$ stretching of the dimer, and absorption at $1190 \mathrm{~cm}^{-1}(v(C-O))$. The unresolved absorption observed at about $1630 \mathrm{~cm}^{-1}$ is due to the $\delta(\mathrm{HOH})$ mode of water used for stabilization of the formic acid. The two bands with maxima at about 2714 and $2560 \mathrm{~cm}^{-1}$ are due to the presence of the formate moieties. This spectrum is consistent with the literature data $(32,33)$ for the prevailing dimeric form of the acid.

The FTIR spectra of $\mathrm{HCOOH}(0.5$ Torr) adsorbed at room temperature on the surface of the $\mathrm{M} \mathrm{nTi-IE}$ catalyst and after $10 \mathrm{~min}$ of evacuation are shown in Fig. 9. The spectra differ from the spectrum of the free acid indicating an interaction of the latter with the catalyst surface. $B$ ands typical for formate species $(31,34,35)$ are detected at $2960\left(v_{\text {as }}\left(\mathrm{CO}_{2}^{-}\right)+\delta(\mathrm{CH})\right), 2874(v(\mathrm{CH}))$, and $2735 \mathrm{~cm}^{-1}$ $\left(v_{s}\left(\mathrm{CO}_{2}^{-}\right)+\delta(\mathrm{CH})\right)$. To these species belongs the group of bands with maxima at 1582, 1573, and $1555 \mathrm{~cm}^{-1}$ due to $v_{\text {as }}\left(\mathrm{CO}_{2}^{-}\right)$and the absorptions at 1368 and $1315 \mathrm{~cm}^{-1}$ which correspond to the $v_{\mathrm{s}}\left(\mathrm{CO}_{2}^{-}\right)$mode of the formate ions, respectively. The splitting in the $\mathrm{CO}_{2}^{-}$stretching vibrations suggests different types of coordination and/or different adsorption centers $(31,34,35)$. The band at $1380 \mathrm{~cm}^{-1}$ can be attributed to the deformation vibration, $\delta(\mathrm{CH})$. This experimental fact shows that the adsorption of formic acid on the surface of the M nTi-IE catalyst is mainly dissociative, leading to formation of $\mathrm{H}$-bonded $\mathrm{OH}$ groups ( $a n$ intense and broad band between 3500 and $3000 \mathrm{~cm}^{-1}$ in the IR spectrum). The water present in the acid contributes also to this absorption. The band at about $1620 \mathrm{~cm}^{-1}$ is attributed to the $\delta(\mathrm{HOH})$ mode of the adsorbed water molecules although the existence of formate species with the same $v_{\text {as }}\left(\mathrm{CO}_{2}^{-}\right)$ frequency cannot be excluded. The weak band at $1690 \mathrm{~cm}^{-1}$ $(v(\mathrm{C}=0))$ together with the unresolved weaker absorption in the $\mathrm{OH}$ stretching region at about $3620 \mathrm{~cm}^{-1}(v(\mathrm{OH}))$ suggests the presence of some undissociated formic acid on the catalyst surface. The former band is red-shifted compared to its position in the spectrum of the free acid which indicates that $\mathrm{HCOOH}$ iscoordinated through the carbonyl oxygen to a L ewis acid site. The surface species formed are stable toward evacuation at room temperature for $10 \mathrm{~min}$. The increased intensity of the bands in the $1580-1300-\mathrm{cm}^{-1}$ region suggests formation of an additional amount of formate species. Finally, the weak negative bands at 3730$3670 \mathrm{~cm}^{-1}$ in the $\mathrm{OH}$ stretching region indicate that the isolated $\mathrm{OH}$ groups in the catalyst are altered during the adsorption of formic acid.

\section{DISCUSSION}

\section{Coordination N umber of $D$ eposited $M$ anganese I ons}

A ccording to the XPS data the ion-exchanged catalyst, $\mathrm{M} \mathrm{nTi-IE}$, contains only $\mathrm{M} \mathrm{n}^{3+}$ ions. M anganese(III) usually forms six- and five-coordinated complexes (24). The sixcoordinated $\mathrm{M} \mathrm{n}^{3+}$ complexes are subject to Jahn-Teller effects $(24,36,37)$ and the absorption spectra are difficult to interpret. The analysis of the literature data (24) shows that five- and six-coordinated $\mathrm{M} \mathrm{n}^{3+}$ ions in bulk coordination compounds have an overlapping region in the visible absorption spectra between 500 and $650 \mathrm{~nm}$ when the 
ligating atom is oxygen. However, they can be distinguished by the adsorption at $1050-1100 \mathrm{~nm}\left({ }^{5} A_{1 g} \rightarrow{ }^{5} B_{1 g}\right)$ for six-coordinate $\mathrm{M} \mathrm{n}^{3+}$ ions and by that at $730-830 \mathrm{~nm}$ for five-coordinated species. B ased on this, it is possible to conclude that the catalyst M nTi-IE contains both five- and sixcoordinate $\mathrm{M} \mathrm{n}^{3+}$ ions: the wide unresolved absorption with a maximum at about $850 \mathrm{~nm}$ is attributed to the $\mathrm{d}-\mathrm{d}$ transition of five-coordinated $\mathrm{M} \mathrm{n}^{3+}$ ions whereas the band at about $1015 \mathrm{~nm}$ can be assigned to the transition ${ }^{5} A_{1 g} \rightarrow{ }^{5} B_{1 g}$ of six-coordinated species which are subject to J ahn-Teller distortion. Probably the concentration of six-coordinated $\mathrm{M} \mathrm{n}^{3+}$ ions is higher. This conclusion is drawn by comparison of the molar absorptivities for the two transitions. The molar absorptivity for the transition ${ }^{5} A_{1 g} \rightarrow{ }^{5} B_{1 g}$ in the sixcoordinated complexes is lower by approximately one order of magnitude than that for the transition at $730-850 \mathrm{~nm}$ in the case of five-coordinated species (24).

\section{L ocalization of the Supported M anganese I ons} on the Surface of Titania

A ccording to the chemical analysis the ion-exchanged catalyst, $\mathrm{MnTi}-\mathrm{IE}$, contains $1.9 \mathrm{wt} \%$ of manganese which corresponds to a surface concentration of $4 \mathrm{M} \mathrm{n}^{3+}$ ions $/ \mathrm{nm}^{2}$. On the anatase surface there are $4-7 \mathrm{Ti}^{4+} / \mathrm{nm}^{2}$ and the concentration of the isolated $\mathrm{Ti}^{4+}-\mathrm{OH}$ groups is not more than $0.5 \mathrm{OH}$ group $/ \mathrm{nm}^{2}(28,29)$. If the anchoring sites are the hydroxyl groups and in the vicinity of the coordinatively unsaturated (cus) $\mathrm{Ti}^{4+}$ ions (assuming one $\mathrm{M} \mathrm{n}^{3+}$ ion per two $\mathrm{Ti}^{4+}$ ions), a monolayer coverage would be reached at maximum 1.9 wt\% of manganese. Hence, the experimentally determined manganese loading in the ion-exchanged catalyst corresponds to a monolayer coverage.

The adsorption of $\mathrm{CO}$ on the activated M nTI-IE sample revealed the presence of two types of $\mathrm{Mn}^{3+}$ ions, which form two kinds of linear $\mathrm{M} \mathrm{n}^{3+}-\mathrm{CO}$ carbonyls with $v(\mathrm{CO})$ stretching frequencies at 2194 and $2187 \mathrm{~cm}^{-1}$, respectively. These two adsorption sites differ in their strength, the former being stronger; i.e., they are characterized by a lower coordinative saturation. B ased on the loading determined by the chemical analysis, it is reasonable to assume that $\mathrm{Mn}^{3+}$ ions are localized mainly in the vicinity of the cus $\mathrm{Ti}^{4+}$ ions. Several types of cus titanium ions exist on the surface of anatase but only $\alpha$ - and $\beta^{\prime}-\mathrm{Ti}^{4+}$ centers can be detected by adsorption of $\mathrm{CO}$ at room temperature (25, 28-30). The so-called $\beta^{\prime \prime}$ - and $\gamma$-Ti ${ }^{4+}$ ions possess low electrophilicity and can be monitored only in low-temperature experiments $(25,30)$. The surface concentration of the $\alpha$ sites is the lowest (29). Consequently, a higher concentration of $\mathrm{M} \mathrm{n}^{3+}$ ions localized in the vicinity of $\beta$ - and $\gamma-\mathrm{Ti}^{4+}$ ions than that of those ions situated in the proximity of the $\alpha-\mathrm{Ti}^{4+}$ sites can be expected. A ccording to visible spectroscopy, the $\mathrm{M} \mathrm{n}^{3+}$ ions are five- and six-coordinate species, the latter being more abundant. The $\mathrm{CO}$ adsorption experiments show that only monocarbonyls are formed; i.e., the manganese species contain only one coordination vacancy. Since the electronic spectra are taken under ambient conditions, it is possible to conclude that after the catalyst activation four- and five-coordinated $\mathrm{M} \mathrm{n}^{3+}$ ions are formed. $\mathrm{H}$ ence, the following localization of the cus $\mathrm{M} \mathrm{n}^{3+}$ ions can be proposed:

(i) The vicinity of the $\beta$ - and $\gamma$-L ewis acid sites on anatase (which represent five-coordinated $\mathrm{Ti}^{4+}$ ions $(28,29)$ ) is occupied by five-coordinated $\mathrm{M} \mathrm{n}^{3+}$ ions (type I). The carbonyls formed with their participation are characterized by the absorption at $2187 \mathrm{~cm}^{-1}$.

(ii) Four-coordinated $\mathrm{Mn}^{3+}$ ions (type II) block the $\alpha$ L ewis sites of the support (four-coordinated $\mathrm{Ti}^{4+}$ ions (28, 29)) and form carbonyls with the $v(\mathrm{CO})$ stretching frequency at $2194 \mathrm{~cm}^{-1}$.

Finally, the existence of five-coordinate $\mathrm{Mn}^{3+}$ ions localized on the sites which correspond to surface $\mathrm{Ti}^{4+}-\mathrm{OH}$ groups participating in the deposition process should be taken into account also. It is believed $(29,30)$ that the $\mathrm{Ti}^{4+}$ ions, to which the residual $\mathrm{OH}$ groups are bound, are fivecoordinated.

No exposed $\mathrm{Ti}^{4+}$ ions are expected on the surface of the $\mathrm{MnTi}$-IE catalyst. H owever, this suggestion cannot be proved unambiguously by room-temperature adsorption of $\mathrm{CO}$. In addition, the close frequencies and the strong absorption of $\mathrm{Mn}^{3+}-\mathrm{CO}$ carbonyls hinder the detection of $\mathrm{Ti}^{4+}-\mathrm{CO}$ carbonyls eventually formed at room temperature.

A ccording to the XPS data and FTIR spectroscopy of adsorbed $\mathrm{CO}$ the impregnated $\mathrm{MnTi}-\mathrm{I}$ catalyst originally contains $\mathrm{M} \mathrm{n}^{2+}$ in addition to the two types of cus $\mathrm{M} \mathrm{n}^{3+}$ ions. Probably, the vicinity of the cus $\mathrm{Ti}^{4+}$ sites of the support is partially occupied by $\mathrm{M} \mathrm{n}^{2+}$ ions as well. The carbonyl band at $2114 \mathrm{~cm}^{-1}$ is assigned to these species. The presence of a high-frequency shoulder to this band indicates that the $\mathrm{Mn}^{2+}$ ions are of two kinds, like the $\mathrm{Mn}^{3+}$ ions. The $\mathrm{Mn}^{2+}$ ionscharacterized by the carbonyl band at $2144 \mathrm{~cm}^{-1}$ are envisaged asproducts of the $\mathrm{CO}$ adsorption. The difference of $30 \mathrm{~cm}^{-1}$ in the stretching frequencies of the corresponding carbonyls is probably due to a difference in the $\sigma$ component of the bond between $\mathrm{M} \mathrm{n}^{2+}$ and $\mathrm{CO}$ (38). The carbonyl band at $2114 \mathrm{~cm}^{-1}$ present in the spectrum after short evacuation (i.e., the corresponding carbonyls are more stable) can be attributed to $\mathrm{M} \mathrm{n}^{2+}$ ions which form a bond with $\mathrm{CO}$ with a considerable $\pi$ contribution. The behavior of the carbonyls characterized by the adsorption at $2144 \mathrm{~cm}^{-1}$ (not observed at low equilibrium pressures of $\mathrm{CO}$ ) indicates that the adsorption centers are weak.

D uring the adsorption, $\mathrm{CO}$ is oxidized to $\mathrm{CO}_{2}$ which further interacts with the basic surface sites, i.e., $\mathrm{O}^{2-}$ ions and $\mathrm{OH}$ groups producing surface carbonates and hydrogen carbonates (see below). The $\mathrm{CO}_{3}^{2-}$ and $\mathrm{HCO}_{3}^{-}$ions can attract electron density via an inductive effect from the neighboring $\mathrm{M} \mathrm{n}^{2+}$ ion formed during the reduction. A s a result the 
electrophilicity of the $\mathrm{Mn}^{2+}$ ions increases. This leads to an enhancement of the $\sigma$ component of the bond between $\mathrm{CO}$ and the metal cation. A s a result the $\mathrm{C}-\mathrm{O}$ stretching frequency is increased. A similar effect was reported by Saussey et al. (39): the $\mathrm{C}-\mathrm{O}$ stretching frequencies of $\mathrm{CO}$ adsorbed on $\mathrm{ZnO}$ before and after $\mathrm{CO}_{2}$ adsorption differ by about $30 \mathrm{~cm}^{-1}$.

Probably the ion-exchanged and impregnated catalysts have different morphologies which affects the rate of $\mathrm{CO}$ chemisorption. This process is much slower for the impregnated catalyst. The reason for this could be the preferential $\mathrm{CO}$ adsorption on sites near the surface of the pellet. This suggests the presence of $\mathrm{M} \mathrm{nO}$ x particles which are not covered by $\mathrm{CO}$ immediately after $\mathrm{CO}$ admission on the $\mathrm{M} \mathrm{nTi-I}$ catalyst.

\section{CO Chemisorption}

The $\mathrm{M} \mathrm{n}^{3+}-\mathrm{CO}$ carbonyls produced on the surface of the catalysts studied are not stable in a $\mathrm{CO}$ atmosphere. This is shown by the decrease in the intensity of the corresponding carbonyl bands and by the appearance of absorption typical for linearly bonded $\mathrm{CO}_{2}$ and various carbonatecarboxylate structures. The formation of $\mathrm{CO}_{2}$ from $\mathrm{CO}$ is associated with the oxidizing properties of $\mathrm{M} \mathrm{n}^{3+}$ ions (40). The involvement of surface $\mathrm{OH}$ groups and the appearance of a series of bands in the carbonate-carboxylate region suggest formation of hydrogen carbonate or/and formate species.

The similarity of the FTIR spectra of adsorbed formic acid to the spectra in the carbonate-carboxylate region ob- tained during $\mathrm{CO}$ adsorption on the surface of the $\mathrm{M} \mathrm{nTi-IE}$ catalyst implies the existence of similar adsorption forms in both cases. The adsorption of formic acid on this catalyst is dissociative, resulting in the appearance of formate species characterized by complex bands in the 1630-1550and $1400-1250-\mathrm{cm}^{-1}$ regions. A similar set of bands, between 1630 and $1550 \mathrm{~cm}^{-1}$ and the complex absorption at 1350-1250 $\mathrm{cm}^{-1}$, is observed upon CO adsorption on the $\mathrm{MnTi}$-IE catalyst. This allows us to attribute these bands to $v_{\text {as }}\left(\mathrm{CO}_{2}^{-}\right)$and $v_{\mathrm{s}}\left(\mathrm{CO}_{2}^{-}\right)$stretching vibrations of formate species, respectively, which are formed during the reactive adsorption of $\mathrm{CO}$. This assignment is supported by the appearance of weak bands at 2940,2890,2845, and $2750 \mathrm{~cm}^{-1}$ on the sample containing $\mathrm{OH}$ groups with the natural isotopic content of hydrogen, their absence in the spectra of a deuteroxylated sample, and the appearance in the latter of a weak absorption at $1050 \mathrm{~cm}^{-1}$. The bands at 2940 and $2750 \mathrm{~cm}^{-1}$ are typical for formate ions $(31,35)$ and are due to the Fermi resonance between the $v(\mathrm{CH})$ fundamental (at $2890 \mathrm{~cm}^{-1}$ ) and combinations or overtones of the bands in the carboxylate region (see Table 1 ). The band at $1050 \mathrm{~cm}^{-1}$ is characteristic for the $\delta(C D)$ mode of the $\mathrm{DCO}_{2}^{-}$ion (31). The pair of bands at 1414 and $1222 \mathrm{~cm}^{-1}$ can be assigned to the splitting of the $v_{3} \mathrm{vi}-$ bration of monodentate carbonate $\left(\Delta v_{3}<300 \mathrm{~cm}^{-1}\right)$ (31) whose $v_{1}$ stretching mode is positioned at $1075 \mathrm{~cm}^{-1}$. The bands at $1668(v(\mathrm{C}=0))$ and $1244 \mathrm{~cm}^{-1}(v(\mathrm{C}-\mathrm{O}))$ together with the sharp band at $3616 / 2668 \mathrm{~cm}^{-1}(v(\mathrm{OH}) / v(\mathrm{OD}))$ are attributed to formic acid formed on the surface of the catalyst $\mathrm{MnTi}$-IE . The band assignment is presented in Table 1.

TABLE 1

Assignment of the FTIR Bands Observed in the Carbonate- $C$ arboxylate R egion during Adsorption of $\mathbf{3 0}$ Torr of $\mathrm{CO}$ at Room Temperature on the Catalysts Studied

\begin{tabular}{|c|c|c|c|}
\hline Catalyst & Frequency $\left(\mathrm{cm}^{-1}\right)$ and mode & Possible assignment & R efs. \\
\hline \multirow[t]{3}{*}{ M nTi-IE } & $\begin{array}{l}2940\left(v_{\text {as }}\left(\mathrm{CO}_{2}^{-}\right)+\delta(\mathrm{CH})\right) \\
2890,2845(\nu(\mathrm{CH})) \\
2735\left(v_{\mathrm{s}}(\mathrm{CO}-)+\delta(\mathrm{CH})\right) \\
1630-1550\left(v_{\mathrm{as}}^{-}\left(\mathrm{CO}_{2}^{-}\right)\right) \\
1380(\delta(\mathrm{CH})), 1350-1250\left(v_{\mathrm{s}}\left(\mathrm{CO}_{2}^{-}\right)\right)\end{array}$ & $\begin{array}{l}\text { Formate species coordinated } \\
\text { to } \mathrm{M} \mathrm{n}^{3+} \text { ions }\end{array}$ & $31,34,35$ \\
\hline & $\begin{array}{l}3616(v(\mathrm{OH})) \\
1668(v(\mathrm{C}=0)), 1244(v(\mathrm{C}-0))\end{array}$ & A dsorbed formic acid & This work \\
\hline & 1414,1222 (splitting of $v_{3}$ vibration) & $\begin{array}{l}\text { M onodentate carbonate } \\
\left(\Delta v_{3}<300 \mathrm{~cm}^{-1}\right)\end{array}$ & 31,34 \\
\hline \multirow[t]{3}{*}{ MnTi-I } & $\begin{array}{l}2710\left(v_{\mathrm{s}}\left(\mathrm{CO}_{2}^{-}\right)+\delta(\mathrm{CH})\right) \\
2600(\mathrm{comb} .1270+1330) \\
1630-1500\left(v_{\mathrm{as}}\left(\mathrm{CO}_{2}^{-}\right)\right) \\
1390(\delta(\mathrm{CH})), 1350-1250\left(v_{\mathrm{s}}\left(\mathrm{CO}_{2}^{-}\right)\right)\end{array}$ & $\begin{array}{l}\text { Formate species coordinated } \\
\text { to } \mathrm{M} \mathrm{n}^{3+} \text { ions }\end{array}$ & $31,34,35$ \\
\hline & $\begin{array}{l}3616(v(\mathrm{OH})) \\
1668(v(\mathrm{C}=0)), 1248(v(\mathrm{C}-\mathrm{O}))\end{array}$ & A dsorbed formic acid & This work \\
\hline & $\begin{array}{l}3650(v(\mathrm{OH})), 1860\left(v_{\mathrm{as}}(\mathrm{C}=0)\right) \\
1422\left(v_{\mathrm{s}}(\mathrm{C}=0)\right), 1194(\delta(\mathrm{OH}))\end{array}$ & $\mathrm{H}$ ydrogen carbonate species & 31 \\
\hline
\end{tabular}


Similar arguments for the interpretation of the bands observed in the carbonate-carboxylate region are applied to the catalyst M nTi-I (see Table 1 and Fig. 7). H owever, this sample displays different behavior during the evacuation at room temperature, allowing the bands at 1680 $\left(v_{\text {as }}(\mathrm{C}=\mathrm{O})\right), 1422\left(v_{\mathrm{s}}(\mathrm{C}=\mathrm{O})\right)$, and $1194 \mathrm{~cm}^{-1}(\delta(\mathrm{OH}))$ to be attributed to hydrogen carbonate species (31). The absorption at $3650 / 2700 \mathrm{~cm}^{-1}$ (which increasessimultaneously with the bands cited above during the evacuation) is also assigned to these species. The latter band corresponds to the $v(O H / O D)$ stretching frequency of the hydrogen carbonate ion.

The positive absorption due to $\mathrm{H} / \mathrm{D}$-bonded $\mathrm{OH} / \mathrm{OD}$ groups which develops simultaneously with the bands in the carbonate-carboxylate region and which is observed on both catalysts is an indication of interaction of the adsorbed forms (formates, carbonates, and/or hydrogen carbonates) with the surface $\mathrm{OH} / \mathrm{O} \mathrm{D}$ groupsoriginally present in the catalysts. $\mathrm{H}$ owever, the alteration of the latter cannot be observed because the expected negative $\mathrm{OH} / \mathrm{OD}$ bands fall in the same region of the strong positive band between $3700-3000$ and $2700-2400 \mathrm{~cm}^{-1}$, respectively.

The complex shape of the bands assigned to formate ions implies the existence of at least three kinds of formate species differing in their structure and type of coordination site, e.g., two types of $\mathrm{M} \mathrm{n}^{3+}$ ions and probably some exposed $\mathrm{Ti}^{4+}$ ions. H owever, exact determination of the coordination type and site(s) is difficult due to the simultaneous development of the corresponding bands during the $\mathrm{CO}$ adsorption and the comparable stabilities of the formate structures toward evacuation at ambient and higher temperatures. The reduced $\mathrm{MnTi}$-IE catalyst displays a less complex spectrum in the carbonate-carboxylate region and the formate species characterized by the absorption at 1550 $\left(v_{\text {as }}\left(\mathrm{CO}_{2}^{-}\right)\right)$and $1340 \mathrm{~cm}^{-1}\left(v_{\mathrm{s}}\left(\mathrm{CO}_{2}^{-}\right)\right)$can be tentatively described as a bridged species $\left(\Delta v=210 \mathrm{~cm}^{-1}(31)\right)$ coordinated to the $\mathrm{M} \mathrm{n}^{3+}$ ions of type I. The argument for this is that part of the $\mathrm{M} \mathrm{n}^{3+}$ ions are left unreduced and produce a carbonyl band at $2189 \mathrm{~cm}^{-1}$.

It is known $(2,41)$ that bulk $\mathrm{Mn}_{2} \mathrm{O}_{3}$ reduced with hydrogen at temperatures above $523 \mathrm{~K}$ is in equilibrium with the product $\mathrm{MnO}$. A ccording to the TPR results (3) on highly dispersed manganese oxides deposited on the surface of $\gamma-\mathrm{Al}_{2} \mathrm{O}_{3}$, the major reduction process of $\mathrm{M} \mathrm{n}^{3+}$ to $\mathrm{M} \mathrm{n}^{2+}$ at low loading (up to $2 \mathrm{wt} \%$ ) is between $500-700 \mathrm{~K}$ and occurs in one step. In the case of catalysts with lower dispersion and higher manganese content a two-step reduction via intermediate formation of $\mathrm{M} \mathrm{n}_{3} \mathrm{O}_{4}$ phase is observed. The ESCA investigations (2) on $\mathrm{Mn} / \mathrm{A} \mathrm{I}_{2} \mathrm{O}_{3}$ catalysts that have been reduced with hydrogen $(773 \mathrm{~K}, 5 \mathrm{~h})$ showed formation of bulk $\mathrm{MnO}$. O ur results show a strong decrease in the population of $\mathrm{M} \mathrm{n}^{3+}$ ions in the ion-exchanged catalysts after reduction with hydrogen. $\mathrm{H}$ owever, the amount of $\mathrm{M} \mathrm{n}^{2+}$ ions detected by adsorption of $\mathrm{CO}$ at room tem- perature is very low and does not differ from that in the oxidized catalyst (Fig. 6). A s already discussed, it probably arises from the interaction of some unreduced $\mathrm{M} \mathrm{n}^{3+}$ ions with the adsorbate. The reduced $\mathrm{MnTi}-\mathrm{I}$ catalyst is inactive toward $\mathrm{CO}$ adsorption. It is possible that, due to agglomeration, the reduced phase does not contain cus $\mathrm{M} \mathrm{n}^{2+}$ ions ( or their amount is very low) and thus cannot be detected by $\mathrm{CO}$ adsorption. H owever, we prefer to interpret the drastic decrease in the $\mathrm{CO}$ chemisorption after the reduction with hydrogen in terms of the strong metal-support interaction (SM SI ) (42). The presently accepted explanation $(43,44)$ for SM SI in supported titania catalysts reduced at temperatures above $573 \mathrm{~K}$ is associated with migration of suboxide titania phase onto the particle of the active phase. Thus, part of the manganese oxide phase is partially covered by $\mathrm{TiO}_{\mathrm{x}}$ and is not accessible to $\mathrm{CO}$ adsorption. E vidence that such structural changes are induced by the reduction is the similarity between the spectra in the $\mathrm{OH}$ region of the reduced M nTi-IE catalyst and the support. It is believed that the suboxide titania phase is a strong reducer and is oxidized by $\mathrm{CO}(25,29)$. This means that the carbonyl band detected at $2189 \mathrm{~cm}^{-1}$ might be due to both unreduced $\mathrm{M} \mathrm{n}^{3+}$ and reoxidized $\mathrm{Ti}^{4+}$ ions. From these experimental results it is difficult to judge if reduction of $\mathrm{M} \mathrm{n}^{3+}$ ions has occurred and the $\mathrm{MnO}$ and/or $\mathrm{M} \mathrm{n}_{2} \mathrm{O}_{3}$ phases are encapsulated by the suboxide phase. Further investigations are needed.

The formation of formate species during the $\mathrm{CO}$ adsorption can be described (34) as a nucleophilic attack of basic $\mathrm{OH}$ group on the carbonyl carbon of a coordinated $\mathrm{CO}$ molecule (Scheme 1). The surface $\mathrm{OH}$ groups which are involved in this reaction are the $\mathrm{Ti}^{4+}-\mathrm{OH}$ groups characterized by the absorption band at $3730 \mathrm{~cm}^{-1}$ (shifted to $2750 \mathrm{~cm}^{-1}$ after the deuteroxylation). The participation of hydroxyls with lower $\mathrm{OH}$ stretching frequencies is not excluded but it could not be monitored. The observed decrease in the intensity of the bands corresponding to the

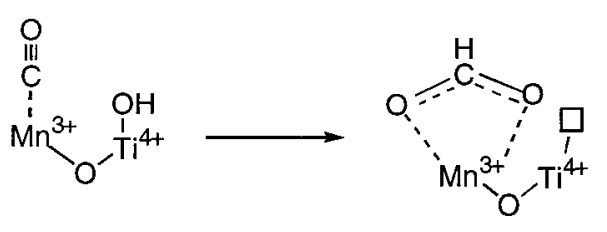

or

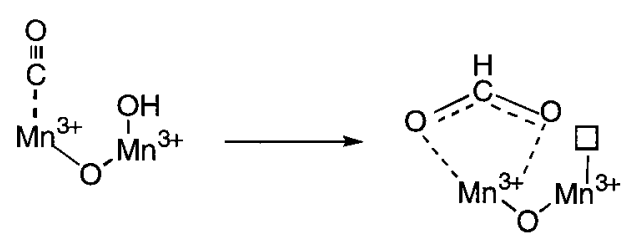

SCHEME 1 


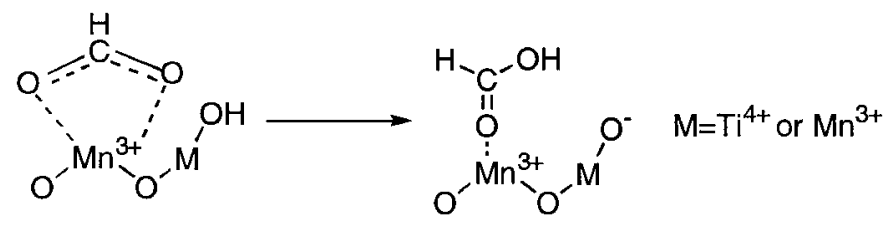

SCHEME 2

$\mathrm{Mn}^{3+}-\mathrm{CO}$ carbonyls and the respective $\mathrm{Ti}^{4+}-\mathrm{OH}$ groups and the parallel growth of the bands due to the formate species support the proposed reaction scheme.

Some molecularly adsorbed formic acid is detected on the surface of the catalyst $\mathrm{M} \mathrm{nTi-IE}$. The formation of $\mathrm{HCOOH}$ can be explained by coordination of a proton from the acidic $\mathrm{OH}$ group with a formate species (Scheme 2).

The experimental results show that the appearance of the formate species is associated only with the $\mathrm{M} \mathrm{n}^{3+}$ ions: the band at $2114 \mathrm{~cm}^{-1}$ due to $\mathrm{M} \mathrm{n}^{2+}-\mathrm{CO}$ carbonyls (catalyst $\mathrm{MnTi-I}$ ) does not decrease in intensity during the $\mathrm{CO}$ adsorption at constant pressure. In contrast, there is an enhancement of itsintensity after prolonged ( $100 \mathrm{~min}$ ) contact of the catalyst with $\mathrm{CO}$; i.e., part of the $\mathrm{Mn}^{3+}$ ions are reduced to $\mathrm{M} \mathrm{n}^{2+}$ in the $\mathrm{CO}$ atmosphere. The $\mathrm{CO}_{2}$ produced is coordinated on the surface and forms carbonates ( $\mathrm{M}$ nTi-IE catalyst) and hydrogen carbonates ( $\mathrm{MnTi}$-I catalyst). The stabilization of the hydrogen carbonate species on the surface of the impregnated catalyst probably is favored by the $\mathrm{M} \mathrm{n}^{2+}$ ions. This suggestion is confirmed by the experimental fact that a similar process occurs to a much smaller extent on the surface of the M nTi-IE catalyst which contains originally only $\mathrm{M} \mathrm{n}^{3+}$ ions.

The importance of $\mathrm{M} \mathrm{n}^{3+}$ ions for formate formation is also demonstrated by the adorption of $\mathrm{CO}$ on the reduced $\mathrm{MnTi}$-IE catalyst. The decrease in the amount of exposed cus $\mathrm{M} \mathrm{n}^{3+}$ causes a significant decrease in the population of the formate species.

Finally, it should be noted that the frequencies of the formate species produced during the $\mathrm{CO}$ adsorption differ slightly from those obtained from formic acid. The reason is the different mechanism of formation of these surface forms which influences their structure. D uring the $\mathrm{CO}$ adsorption, the surface $\mathrm{OH}$ groups and $\mathrm{M} \mathrm{n}^{3+}-\mathrm{CO}$ carbonyls are involved, whereas in the case of $\mathrm{HCOOH}$ the formation of $\mathrm{HCO}_{2}^{-}$species is a result of dissociation of the acid. Variation of the frequencies of the formate ions produced by adsorption of formaldehyde, formic acid, or methanol oxidation on different oxide surfaces is reported also by other authors $(35,45)$.

\section{CONCLUSIONS}

The results of the present investigation show that the application of ion-exchange for deposition of managanese ions on titania (anatase) from manganese(II) chloride so-
Iution ensures a coverage by manganese oxide phase which corresponds to a monolayer. The catalyst prepared by this method contains two kinds of $\mathrm{M} \mathrm{n}^{3+}$ ions differing in their coordinative saturation: five-coordinated $\mathrm{M} \mathrm{n}^{3+}$ ions located in the vicinity of the weaker L ewis acid sites and four-coordinated $\mathrm{M} \mathrm{n}^{3+}$ ions which block the stronger $\mathrm{L}$ ewis acid sites of the support. A small amount of the deposited managanese ions occupies part of the sites of the residual $\mathrm{OH}$ groups of the support participating in the synthesis process. The impregnated catalyst contains a mixture of $\mathrm{M} \mathrm{n}^{3+}$ and $\mathrm{M} \mathrm{n}^{2+}$ species.

The adsorption of $\mathrm{CO}$ at room temperature on the catalysts studied results in the appearance of formate, carbonate, and hydrogen carbonate structures. It is found that the formation of formate species is associated with the $\mathrm{M} \mathrm{n}^{3+}$ ions. The stabilization of the hydrogen carbonates is favored by $\mathrm{M} \mathrm{n}^{2+}$ ions. The reduction of the catalyst studied with hydrogen strongly suppresses the adsorption of $\mathrm{CO}$ and isindicative of the occurrence of a strong metal-support interaction.

\section{ACKNOWLEDGMENTS}

This work was financially supported by the Scientific and Technical R esearch Council of Turkey (TÜB ITA K ), project TBA G - 1706 .

\section{REFERENCES}

1. G rzybek, T., K linik, J., R ogoz, M ., and Papp, H ., J. Chem. Soc., Faraday Trans. 94, 2843 (1998).

2. Strohmeier, B., and Hercules, D. M., J. P hys. Chem. 88, 4922 (1984).

3. Kapteijn, F., van Langeveld, A. D., M oulijn, J. A ., A ndreini, A ., Vuurman, M ., Turek, A. M ., J ehng, J.-M ., and Wachs, I., J. Catal. 150, 94 (1994).

4. B oot, L. A ., Kerkhoffs, M. H. J. V., van Linden, B. T., van Dillen, A . J., G eus, J. W., and van B uren, F. R., A ppl. Catal. A 137, 69 (1996).

5. Konietzni, F., Kolb, U., D ingerdissen, U., and M aier, W. F., J. Catal. 176, 527 (1998).

6. Lo Jacono, M., Schiavello, M., in "Preparation of Catalysts" (B. D elmon, P. A . Jacobs, and G. Poncelet, Eds.), p. 474. Elsevier, A msterdam, 1976.

7. Ellgen, P. C., Bartley, W. J., B hasin, M . M ., and Wilson, T. P., ACS A dv. Chem. Ser. 178, 147 (1979).

8. Kijlstra, W. S., B rands, D. S., and Poels, E. K ., J. Catal. 171, 208 (1997).

9. A ylor, A. W., L obree, L. J., R eimer, J. A ., and B ell, A . T., J. Catal. 170, 390 (1997).

10. Campa, M. C., Pietrogiacomi, D., Tuti, S., Ferraris, G., and Indovina, V., A ppl. Catal. B 18, 151 (1998).

11. Baltanas, M. A ., Stiles, A . B., and K atzer, J. R ., A ppl. Catal. 28, 13 (1986).

12. B altanas, M . A ., Stiles, A . B., and K atzer, J. R ., J. C atal. 88, 362 (1984).

13. K antcheva, M ., Kucukkal, M. U., and Suzer, S., J. M ol. Struct. 482- 483, 19 (1999).

14. Kapteijn, F., Singoredjo, L., van D riel, M., A ndreini, A ., M oulijn, J. A ., R amis, G., and B usca, G., J. Catal. 150, 105 (1994).

15. D avydov, A ., "IR Spectroscopy A pplied to Surface Chemistry of $O X-$ ides." N auka, N ovosibirsk, 1984.

16. Davydov, A. A ., Shchekochikhina, Yu. M., and Keier, N. P., Kinet. K atal. 10, 1341 (1969). 
17. A ngevaare, P. A. J. M., A arden, J. R. S., Linn, J. R ., Zuur, A. P., and Ponec, V., J. E lectron Spectrosc. Relat. Phenom. 54/55, 795 (1990).

18. H arrison, P. G., and Thornton, E. W., J. Chem. Soc., Faraday Trans. 1 74, 2703 (1978).

19. R ebenstorf, B., and L arsson, R ., Z . A norg. A llg. Chem. 453, 127 (1979).

20. B usca, G., J. Catal. 120, 303 (1989).

21. B riggs, D., and Saeh, M . P., "Practical Surface A nalysis," Vol. 1 (Second E dition), p. 128. Wiley, Chichester, 1994.

22. M urray, J. W., D illard, J. G., G iovanoli, R ., M oers, H. M ., and Stumm, W., G eochim. Cosmochim. A cta 49, 463 (1985).

23. Foord, J. S., Jackman, R. B., and A llen, G. C., Philos. M ag. A 49, 657 (1984).

24. Lever, A. B. P., "Inorganic Electronic Spectroscopy” (Second E dition), p. 440. E Isevier, A msterdam, 1984.

25. H adjiivanov, K. I., and K lissurski, D. G., Chem. Soc. Rev. 61 (1996).

26. Busca, G., Saussey, H., Saur, O., Lavalley, J.-C., and Lorencelli, V., A ppl. Catal. 14, 245 (1985).

27. H adjiivanov, K., K lissurski, D., B usca, G., and Lorencelli, V., J. Chem. Soc., Faraday Trans. 87, 175 (1991).

28. H adjiivanov, K . I., D avydov, A . A ., and K lissurski, D. G., K inet. K atal. 29, 161 (1988).

29. H adjiivanov, K., Saur, O., L amotte, J., and L avalley, J.-C., Z. Phys. Chem. 187, 281 (1994).

30. Hadjiivanov, K., L amotte, J., and L avalley, J.-C., L angmuir 13, 3374 (1997).
31. B usca, G., and L orencelli, V., M ater. Chem. 7, 89 (1982).

32. Schrader, B., "R aman/I nfrared A tlas of O rganic Compounds," p. B 304. V CH, Weinheim, 1989.

33. Holly, S., and Sohar, P., in "A bsorption Spectra in the Infrared R egion" (L. Lang and W. H. Prichard, E ds.), p. 105. A kademiai Kiado, Budapest, 1975.

34. K antschewa, M ., A Ibano, E. V., E rtl, G., and K nözinger, A ppl. Catal. 8, 71 (1983).

35. B usca, G., L amotte, J., L avalley, J.-C., and L orencelli, V., J. A m. Chem. Soc. 109, 5197 (1987).

36. G oodenough, J. B., and L oeb, A . L., Phys. R ev. 98, 391 (1955).

37. Jarosch, D., M iner. Petrol. 37, 15 (1987).

38. H adjiivanov, K. I., K antcheva, M. M ., and K lissurski, D. G., J. Chem. Soc., Faraday Trans. 92, 4595 (1996).

39. Saussey, J., L avalley, J.-C., and B ovet, J. C., J. Chem. Soc., Faraday Trans. 1 78, 1457 (1992).

40. H uheey, J. E ., K eiter, E . A ., and K eiter, R . L., "I norganic Chemistry" (Fourth E dition), p. 584. H arper Collins, New York, 1993.

41. Innes, W. B., in "Catalysts" (P. H. E mmet, Ed.), Vol. 2, Chapter 1. R einhold, New York, 1955.

42. Tauster, S. J., Funk, S. C., and Garten, R. L., J. A m. Chem. Soc. 100, 170 (1978).

43. Vannice, M. A ., J. Catal. 74, 199 (1982).

44. H aller, G. L., and R esasco, D. E ., A dv. Catal. 36, 173 (1989).

45. G lisenti, A ., J. Chem. Soc., Faraday Trans. 94, 3671 (1998). 